\title{
Hydrological and climatic responses of Pinus elliottii var. densa in mesic pine flatwoods Florida, USA
}

\author{
Chelcy Rae FORD ${ }^{\mathrm{a}, \mathrm{b}}$, Jacqueline Renée BROOKS ${ }^{\mathrm{c} *}$ \\ a Department of Biology, University of South Florida, Tampa FL 33620-5150, USA \\ b Present address: Warnell School of Forest Resources, University of Georgia, Athens GA 30602-2152, USA \\ c U.S. EPA/NHEERL Western Ecology Division, Corvallis, OR 97333, USA
}

(Received 4 January 2002; accepted 18 September 2002)

\begin{abstract}
Pinus elliottii Engelm. var. densa Little \& Dorman is the only native sub-tropical pine in the US and is now restricted to an estimated $4.5 \%$ of its original area. To understand how this species might respond to changing environments, we examine the relationship between two hydrologic variables and growth of three stands of $P$. elliottii var. densa occurring along a hydrologic gradient using tree-ring records. The two variables were a short-term indicator of water status, precipitation minus potential evapotranspiration (P-PET), and a long-term indicator of water status, runoff $(\mathrm{R})$. Growth at all sites was positively correlated to current growing season P-PET and R, and strongly, negatively correlated with previous winter $\mathrm{R}$. The positive correlation with spring $\mathrm{R}$ was greater in the site with the deepest water table than in sites with shallower water tables. We discuss the potential for root dynamics to explain the relationships between growth and $\mathrm{R}$.
\end{abstract}

south Florida slash pine / Pinus elliottii var. densa / dendrochronology / tree-ring / runoff / potential evapotranspiration

Résumé - Réaction de Pinus elliottii var. densa aux conditions hydrologiques et climatiques dans les forêts de plaine mésoïque. Pinus elliottii Engelm. Var densa Little et Dorman est la seule espèce de pin subtropicale des États-Unis. Elle n'occupe plus que 4,5\% de son aire d'origine. Afin de comprendre comment cette essence pourrait réagir face à un changement des conditions de milieu, nous avons examiné les relations entre deux variables hydrologiques et l'accroissement dans 3 peuplements de $P$. elliottii var. densa situés sur des stations présentant un gradient hydrologique, à partir de mesures de largeur de cernes. Les deux variables étaient d'une part un indicateur à court terme du statut hydrique, à savoir précipitations moins l'évapotranspiration potentielle (P-PET) et d'autre part un indicateur à long terme du niveau de la nappe d'eau dans le sol par mesure de l'écoulement (R). La croissance, dans toutes les stations, était corrélée positivement avec P-PET et R de la saison de végétation en cours ; la liaison est très fortement négative avec le $\mathrm{R}$ de l'hiver précédent. La corrélation positive avec le $\mathrm{R}$ du printemps est plus grande pour la station dont le niveau de la nappe d'eau dans le sol est plus profond que pour les stations à niveau d'eau plus superficiel. La discussion porte sur le potentiel dynamique des racines pour expliquer les relations entre croissance et $\mathrm{R}$.

Slash Pine de Floride du Sud / Pinus elliottii var. densa / dendrochronologie / cernes / écoulement de l'eau / évapotranspiration potentielle

\section{INTRODUCTION}

Recent changes in land-use practices are having a dramatic effect on ecosystem characteristics [7] and are largely driven by changes in hydrology. Faced with the impact of rapid environmental changes and limited resources, Myers et al. [34] identified 25 global hotspots for conservation priorities. Southern peninsular Florida was included as the third-ranked hotspot. Land-use changes in Florida are threatening the remaining natural pine forest ecosystems. Among these pine forest ecosystems, pine flatwoods are characterized by dry, sandy, nutrientpoor soils and a frequent fire-regime (every 3-10 years). Site moisture availability largely controls the productivity of these ecosystems [31] and the dominant canopy species [32]. The mesic pine flatwoods in southern peninsular Florida are dominated by Pinus elliottii Engelm. var. densa Little \& Dorman (south Florida slash pine), the only pine to inhabit the lower third of the Florida peninsula, and the only native subtropical pine in the United States [28]. Currently, the P. elliottii var. densa ecosystem type has been reduced in area by $95 \%$ from pre-settlement conditions [39].

Managers of parks and other areas within critical biodiversity hotspots have begun to preserve and restore P. elliottii var. densa flatwoods throughout south Florida, without specific data on basic long-term abiotic responses of these ecosystems. Local hydrology has a strong effect on species composition and ecosystem productivity in these flatwood systems; thus, understanding hydrological influences is critical for restoring

\footnotetext{
* Corresponding author: Brooks.ReneeJ@epa.gov
} 
these ecosystems. Specifically, managers need information on how P. elliottii var. densa responds to hydrologic variables that can change over time due to climate change or land use alterations, such as precipitation, potential evapotranspiration, river discharge or runoff, and groundwater table fluctuations. This long-term response information could allow managers to assess the impact of potential hydrologic fluctuations and climate change scenarios [44] on the sustainability of the habitat and to develop alternative strategies for conserving habitat if the habitat was potentially vulnerable.

Long-term correlations between tree growth and these variables can be evaluated using tree-ring records $[15,16]$ when records of the hydrologic parameters spanning the length of the tree-ring records exist. Reliable long-term records of precipitation exist for many sites, and can be used to calculate potential evapotranspiration when combined with long-term records of temperature [23]. Subtracting potential evapotranspiration from precipitation provides an estimate of water demand and deficit. Estimates of water supply are also important; and although precipitation records exist, soil water table positions may be a more reliable indicator of water supply than precipitation because the water table is influenced by infiltration and soil storage. Recent efforts to model flatwoods groundwater tables have shown that removal of the canopy layer raised the water table during dry years but not during wet years [43]. This suggests that tree growth may be highly dependent on access to groundwater in dry years; thus a correlation between tree-ring growth and groundwater depth could be expected. However, long-term records of ground water levels generally do not exist, but correlations between ground water and tree growth can be inferred from runoff data because the water table controls runoff in these lowland systems. Runoff can be calculated from river flow for which many longterm records exist.

Myakka River State Park (MRSP), lying in southwest peninsular Florida, is an example of P. elliottii var. densa flatwoods management and restoration. Although decades of fire-suppression in MRSP led to fragmented stands of pine flatwoods, controlled burning and intensive understory management are helping restore the remaining stands and initiate new ones. Three stands of $P$. elliottii var. densa flatwoods occurring along a hydrologic gradient in MRSP were utilized to correlate tree-ring growth and two hydrologic variables - runoff $(\mathrm{R})$ and precipitation minus potential evapotranspiration (P-PET) (i.e. growth as a function of R and P-PET). We also evaluated the differences in growth responses to R and P-PET among sites. We hypothesize that, due to the nature of the sandy soils and the low topographic variation, growth in sites with shallower water tables, and thus more water availability, would have a weaker relationship with water table fluctuations (represented by correlations with $\mathrm{R}$ ) than sites farther from the river with deeper water tables.

\section{MATERIALS AND METHODS}

\subsection{Study area}

This study was conducted in Myakka River State Park in Sarasota and Manatee Counties, Florida (N $27^{\circ} 14^{\prime} 25^{\prime \prime}$, W $82^{\circ} 18^{\prime}$ 50"). From
1895 through 1998 the average annual precipitation of the region was $1314 \mathrm{~mm}$ and the average annual temperature for the region was $22.3^{\circ} \mathrm{C}$ (National Oceanographic and Atmospheric Administration $[35,36])$. MRSP is Florida's largest state park encompassing 11686 ha of land and $22.5 \mathrm{~km}$ of the Myakka River. The park's land was acquired in 1934 and until 1976 a fire-exclusion and suppression management strategy existed; yet, nearly $85 \%$ of the plant communities in MRSP are fire-dependent [25]. The present management strategy is to promote or create conditions under which these plant communities will re-establish (Belinda Perry, MRSP biologist, pers. comm.). The dominant ecosystems in MRSP are fire-maintained dry prairies, pine flatwoods (mesic flatwoods), scrubby flatwoods, and fire-intolerant oak-palm hammocks [25].

\subsection{Site selection and sampling}

Sites were selected to (1) span the range of hydrologic conditions in mesic pine flatwoods within the park, but be relatively close to each other in order to decrease climatic variability between sites, (2) comprise older trees to maximize the length of the tree-ring chronology, and (3) comprise at least 10-20 dominant individuals so that the sample depth of the chronology would stabilize variance. In a related study, we found five stands that met the second two objectives. For this study, we eliminated two of those stands - one because of its geographic distance from the other sites, and the other because of a negative shift in growth due to recent hydrological changes (see [12]).

Within each of the three sites (CG, NP, and SP, Tab. I), average depth to the water table was recorded in the dry season to provide a relative index of water table depth differences among sites. Using a soil auger, two wells at each site were drilled to the water table (one near the maximum and minimum site elevation). After equilibration, water-table depths were recorded and the two values for each site were averaged (Tab. I). For the NP and CG sites, the 2 depth values differed by an average of $15 \mathrm{~cm}$; at the SP site, the wells differed by $1 \mathrm{~m}$ (due to slight rise in elevation in the stand). Understory structure and species composition were recorded (Tab. I).

For all dominant $P$. elliottii var. densa trees in these sites, we recorded $\mathrm{DBH}$, and using a $35 \mathrm{~cm}$ increment borer (Haglöf Inc., Långsele, Sweden), we extracted two increment cores at least $90^{\circ}$ apart at breast height $(1.37 \mathrm{~m})$. Air-dried cores were mounted and sanded to 400 grit at which ring boundaries were clearly visible. Skeleton plots [42, 40], the list method of marker rings [48], and the COFECHA program $[21,24]$ were used to cross-date and ensure that all cores were correctly dated. Cores with numerous false rings or cores with bud traces obscuring annual rings were not included in the final site chronology. Cores were measured to the nearest $0.001 \mathrm{~mm}$ under $40 \times$ stereoscope (Olympus SZ-4045, Japan) magnification with a linear-encoded measurement stage using the Velmex system (Bloomfield, NY), and measurements were digitally recorded using the MEDIR v1.13 program [21].

\subsection{Chronology development and analysis}

For each site, we generated a residual tree-ring index chronology. Index chronologies were created by fitting each series with a negative exponential or linear function, and computing the index by dividing the observed tree-ring values by the expected values [21]. This served to remove the age trend $[15,16]$. Index chronologies fit a second order autoregressive model (AR2), so to remove the autocorrelation from the data, residuals from the autoregressive model were used as the final tree-ring residual index [5, 33]. These residual values were used in all further analyses. We chose to use the residual index in our analyses to avoid using autocorrelated data, which violate the assumptions of the regression analyses (see [33]). In the following analyses, chronologies were truncated at 1936 so that an index value for a particular year included the information for at least $\mathrm{N}$ trees (see Tab. I). 
Table I. Location and properties of Pinus elliottii var. densa dominated flatwoods sites sampled.

\begin{tabular}{|c|c|c|c|c|c|}
\hline Site & Location description & Site understory structure and composition & Soil classification & $\begin{array}{c}\text { WT } \\
\text { depth (m) }\end{array}$ & $\mathrm{N}$ \\
\hline$\overline{\mathrm{CG}}$ & $\begin{array}{l}\text { Clay Gully; on Clay } \\
\text { Gully waterway }\end{array}$ & $\begin{array}{l}\text { Multi-level woody shrubs; Serenoa repens (Bartr.) Small, } \\
\text { Smilax auriculata Walter, Quercus nigra L., Quercus lau- } \\
\text { rifolia Michaux, Sabal palmetto (Walter) Loddiges ex } \\
\text { Schultes \& Schultes f. }\end{array}$ & $\begin{array}{l}\text { Coarse loamy, siliceous, } \\
\text { hyperthermic Typic } \\
\text { Ochraqualfs; poorly } \\
\text { drained; fine sand } \\
\text { overlaying sandy loam }\end{array}$ & 2.09 & 13 \\
\hline NP & $\begin{array}{l}\text { North Park; at MRSP } \\
\text { north boundary }\end{array}$ & $\begin{array}{l}\text { Multi-level woody shrubs; Serenoa repens, Smilax } \\
\text { auriculata, Quercus nigra, Quercus laurifolia, Sabal } \\
\text { palmetto }\end{array}$ & $\begin{array}{l}\text { Coarse loamy, siliceous, } \\
\text { hyperthermic Typic } \\
\text { Ochraqualfs; poorly } \\
\text { drained; fine sand } \\
\text { overlaying sandy loam }\end{array}$ & 2.44 & 7 \\
\hline SP & $\begin{array}{l}\text { Small Palmetto; off } \\
\text { Ranch House Road }\end{array}$ & $\begin{array}{l}\text { Even-level herbaceous; Serenoa repens, Ilex glabra } \\
\text { (L.) Gray, Myrica cerifera L., Smilax auriculata, } \\
\text { Hypericum tetrapetalum Lam. }\end{array}$ & $\begin{array}{l}\text { Sandy, siliceous, } \\
\text { hyperthermic Alfic } \\
\text { Haplaquod; poorly } \\
\text { drained; fine sand } \\
\text { overlaying fine sandy } \\
\text { loams }\end{array}$ & 2.95 & 18 \\
\hline
\end{tabular}

Notes: Water table (WT) measurements were taken on 25 May 1999 and are reported as the average of 2 wells at each site. All other data were collected March-July 1998. N indicates the number of individual trees comprising the final site chronology (in all cases this number is less than the actual number of trees sampled and aged in the site).

The abiotic variables of precipitation minus potential evapotranspiration (P-PET) and river runoff (R) were calculated using the following data: regional precipitation (FL Region 4, [35]), maximum and minimum temperature data (Arcadia FL station, [36]), dew point temperature $\left(\mathrm{T}_{\text {dew }}=\mathrm{T}_{\min }-2.5^{\circ} \mathrm{C}\right)$; and Myakka River flow data [45]. The first series, P-PET, is a Penman-Monteith based estimate of potential evapotranspiration (PET) subtracted from regional precipitation $(\mathrm{P})$. This variable was calculated using equation $4 \mathrm{a}$ from $\mathrm{Hogg}$ [23] adapted for our study area:

$$
\mathrm{PET}=0.5 \times\left[\left(\mathrm{SVP}_{\text {max }}+\mathrm{SVP}_{\text {min }}\right)-\mathrm{SVP}_{\text {dew }}\right] \times 93 \times e^{\frac{\text { Alt. }}{9300}}
$$

where Alt. is the site altitude or elevation, and SVP is the saturation vapor pressure at a maximum, minimum or dew point temperature. SVP was calculated from temperature according to the Tetens formula [3]. Runoff (R) was calculated by converting Myakka River flow data from volume $\left(\mathrm{ft}^{3} \mathrm{~s}^{-1}\right)$ to depth $\left(\mathrm{mm}\right.$ month $\left.^{-1}\right)$ over the contributing watershed area. Runoff represents a local variable for river flow and soil water-table dynamics, and incorporates an integrating time-lag factor (soil water storage) that the P-PET variable does not.

Simple correlation and multiple linear regression models were used to determine the relationship between the abiotic parameters and the tree-ring residual index. These linear regression models have the general form

$$
\mathrm{y}=\beta_{0}+\beta_{1} \mathrm{x}_{1}+\beta_{2} \mathrm{x}_{2}+\ldots+\beta_{\mathrm{i}} \mathrm{x}_{\mathrm{i}}
$$

where $x_{i}$ represents the independent variables correlated with the tree-ring residual index, such as seasonal values of R and P-PET; $\beta_{\mathrm{i}}$ represents the coefficients of those independent variables; and y represents the dependent variable of tree-ring width. Two years of seasonal data (4 seasons of the current and previous years) of P-PET and $\mathrm{R}$ were correlated with each year of each site's tree-ring residual index chronology (16 independent variables in total). In other words, each year of the tree-ring residual index chronology was compared with and regressed against its current year and previous year seasonal data (e.g. tree-ring growth in 1980 was correlated with and regressed against seasonal climate data from 1980 and 1979). Correlations and regressions were based on an $\mathrm{N}$ of 59 , which is all the years compris- ing the tree-ring record. Seasonal timeframes were defined as: winter (Dec-Feb), spring (Mar-May), summer (Jun-Aug), and fall (SepNov). Seasonal data were used rather than monthly to minimize the number of potential predictor variables in the regression models, and thereby potential spurious correlations. Data from all seasons were included because: (1) P. elliottii shows appreciable diameter growth during all 12 months of the year at this latitude [27], (2) the carbon dynamics of the previous year can influence diameter growth of the present year, and (3) this species generally retains its needles for two years and thus total leaf area is a function of needle production from the previous year and the current year.

Multiple regression models of all combinations and permutations of seasonal variables were generated using SAS software (v6.01, Carey, NC). Due to multicolliniarity, a final regression model was chosen for each site based on the lowest $\mathrm{Cp}$ statistic and the Bayesian Information Criterion (BIC) value and biological meaning. The $\mathrm{Cp}$ statistic balances the residual sum of squares with the number of predictor variables, while the BIC statistic balances the maximum likelihood against the number of predictor variables [8]. Low values of these statistics indicate maximum predictive power of the model with the fewest number of predictors. The significance of the final model for each site was evaluated with the F statistic (Generalized Linear Model). Variance inflation factors (VIF) for each variable in the final models were computed to evaluate multicolliniarity. Models including variables with a VIF over 5 were considered to have multicolliniarity problems and not considered for the final model.

\section{RESULTS}

\subsection{Hydrological patterns}

At this study location, the winter season was relatively dry with PET exceeding $\mathrm{P}$, and $\mathrm{R}$ approaching $0 \mathrm{~mm} \mathrm{month}^{-1}$ (Fig. 1). The spring season had similar precipitation inputs as winter; but as temperature increased, PET also increased, making April and May the driest months of the year with the lowest runoff. Depths to water table reached annual maxima in May [9]. The onset of the summer rainy season occurred during 


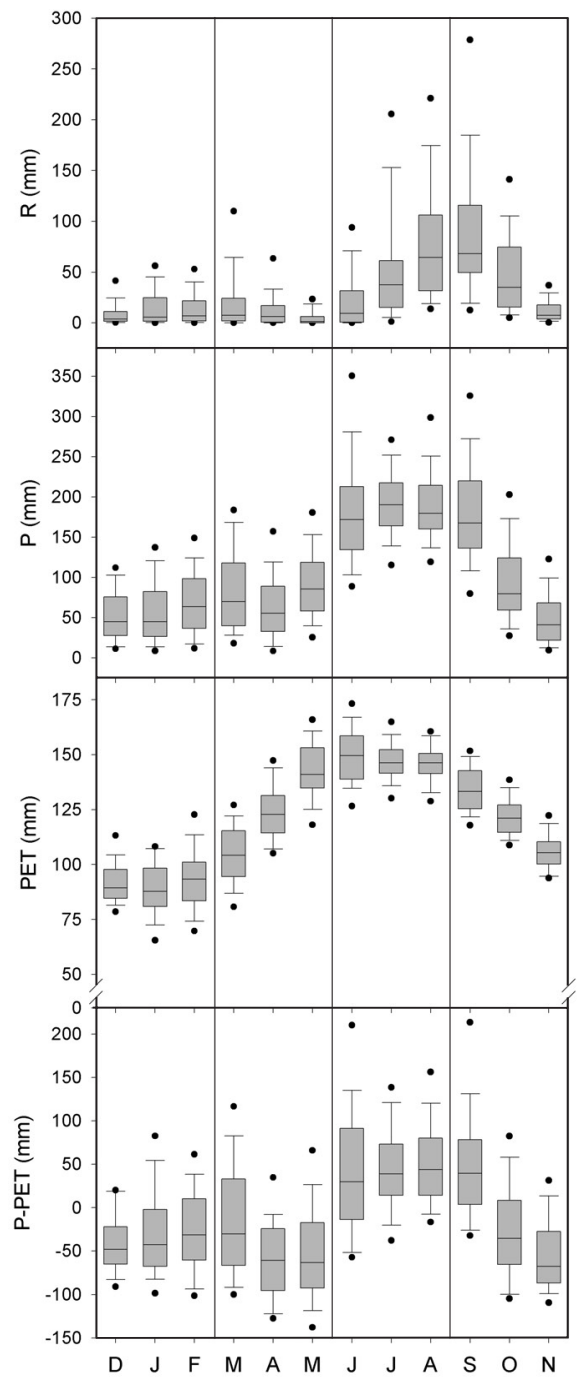

Figure 1. Average monthly abiotic data used in correlation and regression analyses. Runoff (R) data presented are 1936-1998 averages, and regional precipitation $(\mathrm{P})$ and potential evapotranspiration (PET) data presented are 1936-1996 averages. Vertical dividing lines denote seasons used in analyses. Boxes show the median (line), 25th and 75th percentile (box ends). The box whiskers are the 10th and 90th percentile. The 5th and 95th percentile are denoted as points.

June, with median precipitation increasing to $172 \mathrm{~mm}$, which exceeded the evaporative demand. Runoff also increased during the summer, while P-PET remained relatively constant and positive. During all other seasons except summer, P-PET was negative. In the fall, precipitation, runoff and P-PET steadily decreased.

\subsection{Stand ages and chronologies}

The year of establishment (measured at breast height) for trees in this study ranged over a 66-year period (Fig. 2). Trees in all sites were of a similar age distribution (Fig. 2). Average first-year-of-growth of $P$. elliottii var. densa trees sampled was 1933, with the oldest individual establishing in 1888 and

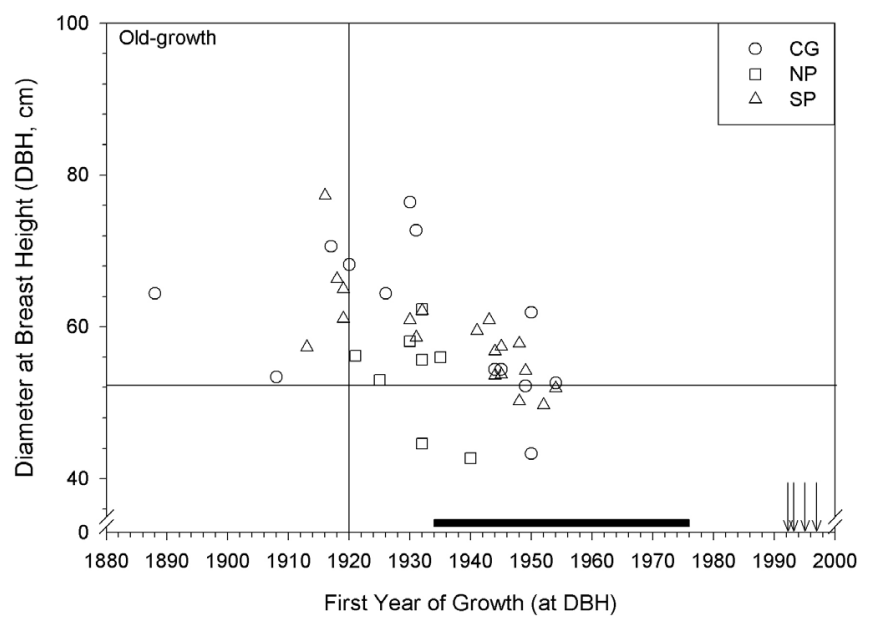

Figure 2. Diameter at breast height $(\mathrm{DBH})$ and first year of growth for Pinus elliottii var. densa stands sampled. Dark bar represents the period of fire suppression and arrows indicate years of prescribed burns in the SP site. Trees with DBH greater than $53 \mathrm{~cm}$ and age greater than 80 years are defined as old growth. (Some trees included in this figure were dropped from the final chronologies due to bud scars or other tree-ring problems. See methods for more details.)

the youngest trees establishing in the 1950s. This, however, is an underestimate of the true tree age because this is the first year of growth determined at breast height. Because we only collected data on dominant individuals, we cannot determine actual recruitment rates; however, many of these dominant individuals were recruited during the early decades of firesuppression (1934-1976, Fig. 2). Average tree diameter in the chronologies was $58.3 \mathrm{~cm}$ and for the different sites, ranged between $53.5 \mathrm{~cm}$ and $60.7 \mathrm{~cm}$. Large trees, those above $55 \mathrm{~cm}$ in diameter, ranged between 46 and 112 years of age, which indicates significant variation in growth among and within the sites.

The residual index chronology developed for each $P$. elliottii var. densa site (Fig. 3) had a high signal-to-noise ratio with intercorrelation coefficients of $\mathrm{NP}=0.454, \mathrm{CG}=0.561$, and $\mathrm{SP}=0.565$. This indicates that within sites, trees had a synchronous tree-ring pattern, and thus were responding to the same climatic signal.

\subsection{Correlations and regression parameters}

Both $\mathrm{R}$ and P-PET seasonal variables were significantly correlated with tree-ring growth and the general pattern was similar for the two variables (Fig. 4). The previous year's climate was negatively correlated with growth, while the current year's climate was positively correlated. For R, a proxy for soil and water table dynamics, two patterns were consistent in all three sites. First, tree-ring growth was positively correlated with $\mathrm{R}$ in the dry, spring season of the current year (Fig. 4). Water tables and runoff were at the lowest point during May, with an average of $5.1 \mathrm{~mm}$ (Fig. 1). We expected the SP site to have a stronger correlation with spring $\mathrm{R}$ than the other sites, because it had the deepest water table; however, the correlation coefficient was only slightly higher: $\mathrm{CG}=0.23$, 


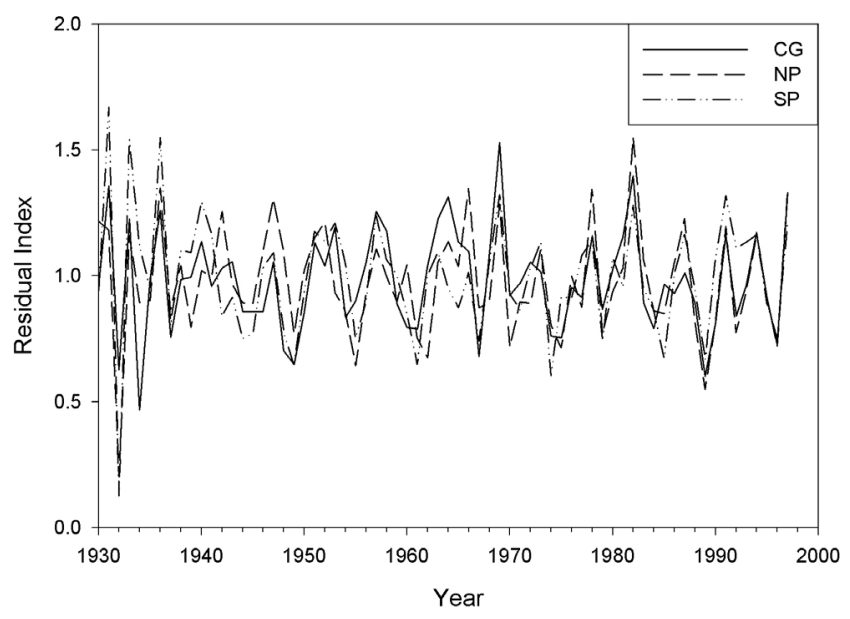

Figure 3. Residual index chronologies for Pinus elliottii var. densa stands sampled shown during the common period of all abiotic data records, 1936-1997.

$\mathrm{NP}=0.22, \mathrm{SP}=0.29$. Furthermore, spring $\mathrm{R}$ was not a significant predictor of growth in any of the best models (Tab. II). The second consistent pattern with runoff in all sites was that tree-ring growth was negatively correlated to the previous year's winter runoff. This correlation became stronger as the depth to the water table increased among sites: $\mathrm{CG}=-0.30$, $\mathrm{NP}=-0.35, \mathrm{SP}=-0.50$. This suggests that tree-ring growth was relatively low when the previous winter experienced high runoff, or high water tables. During this time (Dec-Feb), PET was also at its lowest. These months normally experience low runoff and evaporative demands below $100 \mathrm{~mm} \mathrm{month}^{-1}$. All other months during the year experience evaporative demands in excess of $100 \mathrm{~mm} \mathrm{month}^{-1}$.

For the meteorological indicator of water status, P-PET, we found that growth had a strong positive correlation with spring, summer and fall P-PET during the current year in all three sites. In other words, during the current year if P-PET was high compared to the seasonal average, tree-ring growth was high. Also among sites, correlations with fall and/or spring P-PET were the highest. This suggests that tree-ring growth was high when a favorable water balance coincided with the potentially water-limiting seasons. Interestingly, for the NP and CG sites, when the previous year's P-PET was greater than average, tree-ring growth in the current year was low.

The regression models that best explained the variance in the chronology contained four variables (Tab. II) - at CG, four variables explained $43.8 \%$; at NP, four variables explained $40.1 \%$; and at SP, four variables explained $54.8 \%$. The maximum amount of variance that could be explained by including all 16 climatic variables was $49.6 \%$ for $\mathrm{CG}$ and NP, and $63.7 \%$ for $\mathrm{SP}\left(\mathrm{r}^{2}\right.$ statistic); so these four variables in the selected models explained $88.3 \%, 80.8 \%$, and $86 \%$ of the explainable variance in the chronologies, respectively. Tree-ring growth at sites with shallow water tables, CG and NP, had the highest amount of partial variability explained by spring P-PET. This

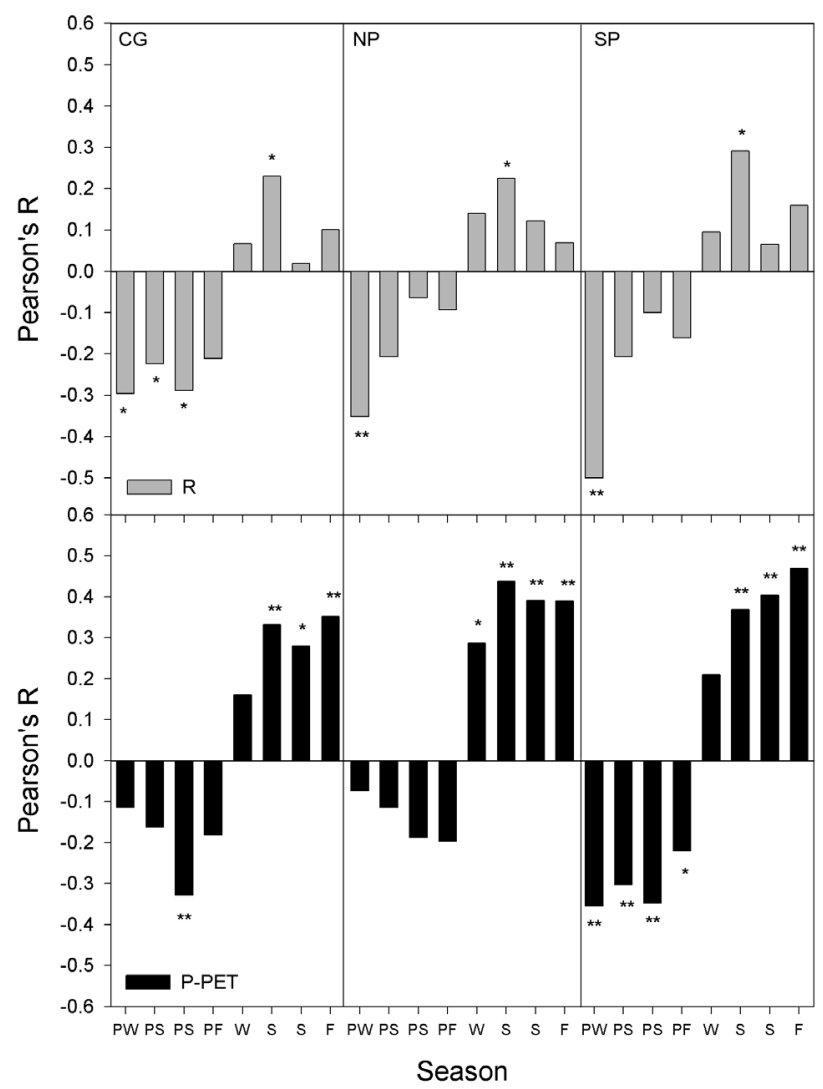

Figure 4. Correlation coefficients between seasonal P-PET and R variables and each site's residual tree-ring index chronology. Seasonal codes: $P$ indicates the previous year and W, S, S, F stand for winter (Dec-Feb), spring (Mar-May), summer (Jun-Aug), and fall (Sep-Nov). Significant correlations are marked with asterisks at the $\alpha=0.05(*)$ and $\alpha=0.01(* *)$ levels.

variable was also the best single predictor of growth for these sites explaining $11 \%$ and $19 \%$ of the variance alone, and spring P-PET appeared in all highly ranked models for these sites (data not shown). In contrast, the site with the deepest water table, SP, had the highest amount of partial variance explained by the previous winter R (Tab. II). Also the best single predictor, winter $\mathrm{R}$, accounted for $25 \%$ of the tree ring variation at the SP site. Interestingly, spring P-PET was a relatively weak predictor of growth at this site and did not appear in any of the highly ranked models. Fall P-PET was more important at this site, and accounted for $22 \%$ of the variance as a single predictor.

In all sites, previous winter $\mathrm{R}$ was included in the best model and was negatively related to growth. This correlation became stronger as depth to water table increased. In general, $\mathrm{R}$ variables were only significant from the previous year, and not the current year. In contrast, significant P-PET variables were both from the previous and the current years. Current year P-PET variables were always positively correlated with growth and were more important in the models than previous year P-PET variables, which were always negatively correlated with growth. 
Table II. Multiple linear regression model summaries for Pinus elliottii var. densa sites in MRSP.

\begin{tabular}{|c|c|c|c|c|c|c|c|c|c|}
\hline \multirow[b]{2}{*}{ Site } & \multicolumn{9}{|c|}{ Model } \\
\hline & Equation & $\mathrm{r}^{2}$ & Adj. $r^{2}$ & $\mathrm{t}$ & $\mathrm{F}$ & $\mathrm{p}$ & $\mathrm{BIC}$ & $\mathrm{Cp}$ & VIF \\
\hline \multirow[t]{5}{*}{$\mathrm{CG}$} & $\mathrm{y}=1090.88+0.44 \mathrm{x}_{1}-0.41 \mathrm{x}_{2}-0.34 \mathrm{x}_{3}-0.22 \mathrm{x}_{4}$ & 0.438 & 0.396 & & 10.521 & 0.0001 & 594.5 & -2.150 & \\
\hline & where $\mathrm{x}_{1}=$ spring P-PET & & & 4.058 & & 0.0002 & & & 1.137 \\
\hline & $\mathrm{x}_{2}=$ previous summer $\mathrm{R}$ & & & -3.764 & & 0.0004 & & & 1.113 \\
\hline & $\mathrm{x}_{3}=$ previous summer P-PET & & & -2.865 & & 0.0059 & & & 1.336 \\
\hline & $\mathrm{x}_{4}=$ previous winter $\mathrm{R}$ & & & -1.801 & & 0.0773 & & & 1.381 \\
\hline \multirow[t]{5}{*}{ NP } & $\mathrm{y}=1091.01+0.43 \mathrm{x}_{1}-0.36 \mathrm{x}_{2}-0.49 \mathrm{x}_{3}+0.38 \mathrm{x}_{4}$ & 0.401 & 0.357 & & 9.049 & 0.0001 & 605.7 & 0.901 & \\
\hline & where $\mathrm{x}_{1}=$ spring P-PET & & & 3.638 & & 0.0006 & & & 1.256 \\
\hline & $\mathrm{x}_{2}=$ previous fall P-PET & & & -2.996 & & 0.0041 & & & 1.317 \\
\hline & $\mathrm{x}_{3}=$ previous winter $\mathrm{R}$ & & & -2.851 & & 0.0062 & & & 2.629 \\
\hline & $\mathrm{x}_{4}=$ previous winter P-PET & & & 2.178 & & 0.0338 & & & 2.820 \\
\hline \multirow[t]{5}{*}{ SP } & $\mathrm{y}=1302.151-0.54 \mathrm{x}_{1}+0.47 \mathrm{x}_{2}-0.24 \mathrm{x}_{3}-0.19 \mathrm{x}_{4}$ & 0.548 & 0.514 & & 16.334 & 0.0001 & 579.7 & 3.429 & \\
\hline & where $\mathrm{x}_{1}=$ previous winter $\mathrm{R}$ & & & -5.703 & & 0.0001 & & & 1.087 \\
\hline & $\mathrm{x}_{2}=$ fall P-PET & & & 5.099 & & 0.0001 & & & 1.026 \\
\hline & $\mathrm{x}_{3}=$ previous summer $\mathrm{R}$ & & & -2.323 & & 0.0239 & & & 1.263 \\
\hline & $\mathrm{x}_{4}=$ previous fall $\mathrm{R}$ & & & -1.891 & & 0.0639 & & & 1.182 \\
\hline
\end{tabular}

Notes: All regression coefficients are standardized and listed in order of significance. All models were developed using the Residual ring width index chronology from each site, and 2 years of seasonal P-PET and R data (4 seasons of the current and previous years for each variable). For all models, $\mathrm{N}$ (sample number of years) $=59$ and Total $\mathrm{df}=58$. Collinearity diagnostics include the Bayesian Information Criterion (BIC), Mallow's $\mathrm{Cp}$, and Variance Inflation Factor (VIF).

\section{DISCUSSION}

We found that growth of mesic Pinus elliottii var. densa stands were related to both too little and too much water. Specifically, higher levels of precipitation, relative to evaporative demand (indicated by P-PET) were associated with increased growth in the current year's spring, summer and fall seasons. P-PET had a stronger relationship with growth at sites with shallower water tables than at sites with deeper water tables. High water tables (as indicated by runoff) in the current year's spring were also positively correlated with growth, while previous winter flooding was strongly and negatively correlated with growth. Flooding in the previous winter had a more negative relationship with growth than flooding in the current year.

Long-term climatic relationships between $P$. elliottii var. densa growth and current growing season P-PET were positive (Fig. 4). Specifically, spring P-PET was strongly correlated with growth in the two sites with the highest water table (Tab. II). This relationship indicates that too little precipitation during the spring dry season is a limiting factor of photosynthesis and thus growth, even though the water table is generally less than $3 \mathrm{~m}$ below the surface during this time. Also working with peninsular Florida Pinus elliottii populations, Foster and Brooks [14] quantified the tree-ring growth correlation with precipitation. They found that dry season precipitation positively affected growth for pines growing in xeric areas, as has been shown for many southern yellow pines [19, $20,37,46]$. They also found that for pines growing within a meter of the water table in more mesic sites, no significant correlation with precipitation existed. Our results suggest that for pines growing in mesic areas, a variable such as P-PET may be better related to growth in times of high water demand than precipitation alone, because P-PET indicates the site's effective water supply.

In the months comprising the spring and fall seasons, temperature and light regimes are favorable for growth; however, precipitation is limited, and evaporation potential is high, leading to negative P-PET values (Fig. 1). These conditions can facilitate stomatal closure and higher respiration $[1,6]$, thus reducing growth. Vapor pressure deficit values of $>2 \mathrm{kPa}$ have been shown to limit net $\mathrm{CO}_{2}$ exchange in $P$. elliottii during the dry spring season [4], indicating stomatal closure effects on carbon assimilation under dry conditions. Interestingly, the dry hot spring is also the time when shoot and root elongation are occurring [17, 18, 22], putting further demands on carbohydrate supplies and thus potentially increasing the sensitivity of stem growth to any climate fluctuations during this time of year. In spite of the dry weather, total plant carbon gain is at its seasonal maximum during spring [4]; thus, any climate variation in potential evapotranspiration and precipitation could have a significant impact on the total carbon accumulated in any year. In our study, annual growth at two sites was highly correlated with spring P-PET, indicating the sensitivity of carbon gain to meteorological conditions during this time.

In addition to short-term water availability (P-PET), access to groundwater as indicated by runoff $(\mathrm{R})$ was strongly related 
to the growth of these old $P$. elliottii var. densa. Specifically, high water tables in the spring were positively related to $P$. elliottii var. densa tree growth, which is in agreement with the effects of spring P-PET discussed above; however, it was not a significant predictor of growth (Tab. II). In contrast, previous winter flooding was negatively related to growth in all sites. When comparing between sites, we found that previous year's winter flooding had a more negative relationship with tree growth in sites with deeper water tables. This negative relationship may be explained by $P$. elliottii root dynamics coupled with winter water table positions. White and Pritchett [47] showed that fine root biomass of P. elliottii tended to concentrate higher in the soil profile with a shallower water table. If water tables were high during periods of root growth and mortality, then most of the fine root biomass would be concentrated in the upper soil horizons, and root proliferation into deeper soil horizons during the spring could be reduced (see [38] subroutine WATER). With shallow functional rooting zones, growth and carbon gain during dry periods when potential evapotranspiration exceeds precipitation could be limited by access to water [26, 29]. Recently Shan et al. [41] showed that in control (no fertilization or understory herbicide treatments) P. elliottii plantations growing in north Florida, fine root $(<2 \mathrm{~mm}$ diameter) production peaked in summer when water tables are generally high (Fig. 1) and mortality peaked during the winter. One might expect that fine roots in a saturated soil might be more likely to die (hypoxia) than roots in a more aerated zone. Shan et al. also suggest that fine root life spans may be as long as three years in this species because they found that total fine root production $\left(7.0 \mathrm{Mg} \mathrm{ha}^{-1}\right)$ was three times total root mortality $\left(2.0 \mathrm{Mg} \mathrm{ha}^{-1}\right)$, [41]. This long lifespan would help in understanding how the water table in the previous winter might have a stronger relationship with growth than the water table in the current winter. If water tables are higher than normal in the winter, they are likely to be higher than normal in the spring, resulting in a positive relationship with growth. However if the following year is dryer but the fine roots are concentrated higher in the soil profile because the water table was high during the preceding winter, then dry spring months when water tables are at their lowest could have a much greater impact on growth $[11,30]$.

\section{CONCLUSIONS}

Water availability during times of high demand (P-PET) as well as access to groundwater (as indicated by runoff, R), were both important variables in understanding growth patterns of these old-growth P. elliottii var. densa during the past century. Although detecting tree ring growth associations with abiotic variables, such as $\mathrm{P}$ and temperature, are common practice, we know of only one other study that used Penman-Monteith potential evapotranspiration variables [2], and few others that synthesize abiotic variables into meaningful physiological variables [13]. Although most tree-ring studies focus on examining growth patterns in hot or cold arid environments, our study shows that trees growing in subtropical mesic habitats hold promise for detecting long-term correlations with climate and hydrology.

In planning restoration activities, land and water managers benefit by understanding species-specific growth characteris- tics. Restoring flatwoods stands in MRSP in the face of changing land-use, river-flow inputs and climate will prove challenging, but the knowledge of historical growth patterns derived from tree-ring records can provide a useful tool for reducing the uncertainty of specific management practices. Managers have no control over the climate; however, the timing of management activities can take into account potential stresses from the environment. For example, a high water table during winter is correlated with reduced growth in the following year, potentially because of its impact on fine root mortality. El Niño events in Florida often produce wet winters with high levels of flooding in some river systems. After such an event occurs, managers could avoid management practices that could stress roots in the upper horizon, such as prescribed burning. On the other hand, high precipitation in the spring with low potential evapotranspiration produces conditions favorable to growth. Thus, potentially stressful management activities could be scheduled during these times when the trees might have the carbon reserves necessary to recover from any adverse effect.

In addition, activities that alter water status of the ecosystem could have significant impacts on the growth of these remnant old-growth stands. Changes in land management or use in the upper watershed could alter the water table of these remaining systems inside MRSP. For example, tree removal from deforestation and urbanization in the upper watershed could significantly elevate the position of the water table near the river due to decreased plant transpiration. Furthermore, increased land area of irrigated crops in the upper watershed has increased flow in the Myakka River system over the last couple of decades. This hydraulic alteration has caused severe mortality in a hardwood swamp upstream of MRSP [10], and some mortality in riparian communities within MRSP [12]. Other $P$. elliottii var. densa stands in MRSP are experiencing decline, but a direct correlation between elevated river flows and decreased growth could not be made [12]. In the current study, we indicate that hydraulic fluctuations could impact rooting depth. Direct studies should be done to confirm this root hypothesis, but until then park managers could assume that the rising water table from increased irrigated crop land area could be causing rooting depths to be shallower in these remnant stands. If state water managers are successful in returning flows to historical levels, these stands could be more acutely vulnerable to drought than they had been in the recent past. To avoid this potential decline in P. elliottii var. densa, park managers could try to concurrently reduce competition for water with the understory species in these stands.

Acknowledgements: The Manasota Basin Board of the Southwest Florida Water Management District, Grant No. 98CON000125, funded the main part of this study. Additional funding was provided by the University of South Florida and the U.S. Environmental Protection Agency. This manuscript has been subjected to the Agency's peer and administrative review, and it has been approved for publication as an EPA document. Mention of trade names or commercial products does not constitute endorsement or recommendation for use. Our thanks are extended to the MRSP staff, who were critical to the success of this study. We thank P. Benshoff, R. Dye, H. GrissinoMayer, E. McCoy, R. Oches, B. Perry, D. Tomasko, for support, and S. Blair and T. Foster for field assistance. Special thanks go to $\mathrm{M}$. Cleaveland, L. Donovan and Lab, J. Miniat, C. McFarlane, R. Teskey, 
D. Tomasko and two anonymous reviewers for comments on earlier versions of this manuscript.

\section{REFERENCES}

[1] Amthor J.S., Respiration in a future, higher-CO2 world, Plant Cell Environ. 14 (1991) 13-20.

[2] Brooks J.R., Flanagan L.B., Ehleringer J.R., Responses of borea conifers to climate fluctuations: indications from tree-ring widths and carbon isotope analysis, Can. J. For. Res. 28 (1998) 524-533.

[3] Buck A.L., New equations for computing vapor pressure and enhancement factor, J. Appl. Meteorol. 20 (1981) 1527-1532.

[4] Clark K.L., Gholz H.L., Moncrieff J.B., Cropley F., Loescher H.W. Environmental controls over net exchanges of carbon dioxide from contrasting Florida ecosystems, Ecol. Appl. 9 (1999) 936-948.

[5] Cook E.R., A time series analysis approach to tree-ring standardization, Ph.D. Watershed Management thesis-University of Arizona, Tucson, 1985.

[6] Cropper W.P., Gholz H.L., In situ needle and fine root respiration in mature slash pine (Pinus elliottii) trees, Can. J. For. Res. 21 (1991) 1589-1595.

[7] Dale V.H., The relationship between land-use change and climate change, Ecol. Appl. 7 (1997) 753-769.

[8] Draper N.R., Smith H., Applied Regression Analysis, John Wiley $\&$ Sons, Inc., New York, 1981.

[9] Duever M.J., McCollom J.M., Hydrologic study within the Myakka River State Park, Ecosystem Research Unit, National Audubon Society, Final C-6415, Naples, 1990.

[10] Ernst K.A., Brooks J.R., Prolonged flooding decreased stem density, tree size and shifted composition towards clonal species in a central Florida hardwood swamp, For. Ecol. Manage. 173 (2003) 261-279.

[11] Ewe S.M.L., Sternberg L.d.S.L., Busch D.E., Water-use patterns of woody species in pineland and hammock communities of South Florida, For. Ecol. Manage. 118 (1999) 139-148.

[12] Ford C.R., Brooks J.R., Detecting ecosystem response to increasing river flow in southwest Florida, USA, For. Ecol. Manage. 160 (2002) 45-64

[13] Foster J.R., LeBlanc D.C., A physiological approach to dendroclimatic modeling of oak radial growth in the midwestern United States, Can. J. For. Res. 23 (1993) 783-798.

[14] Foster T.E., Brooks J.R., Long-term trends in growth of Pinus palustris and Pinus elliottii along a hydrological gradient in central Florida, Can. J. For. Res. 31 (2001) 1661-1670.

[15] Fritts H.C., Dendroclimatology and Dendroecology, Quatern. Res. 1 (1971) 419-449.

[16] Fritts H.C., Tree Rings and Climate, Academic Press, London, 1976.

[17] Gholz H.L., Hendry L.C., Cropper W.P., Organic-matter dynamics of fine roots in plantations of slash pine (Pinus elliottii) in north Florida, Can. J. For. Res. 16 (1986) 529-538

[18] Gholz H.L., Cropper W.P., Carbohydrate dynamics in mature Pinus elliotti var. elliottii trees, Can. J. For. Res. 21 (1991) 1742-1747.

[19] Grissino-Mayer H.D., Rosenberger M.S., Butler D.R., Climatic response in tree rings of loblolly pine from north Georgia, Phys. Geogr. 10 (1989) 32-43.

[20] Grissino-Mayer H.D., Butler D.R., Effects of climate on growth of shortleaf pine (Pinus echinata Mill.) in northern Georgia: A dendroclimatic study, Southeastern Geographer 33 (1993) 65-81.

[21] Grissino-Mayer H.D., Holmes R.L., Fritts H.C., The international tree-ring data bank program library version 2.1 user's manual, Laboratory of Tree-Ring Research, University of Arizona, Tucson, AZ, 1997.

[22] Hendry L.C., Gholz H.L., Aboveground phenology in north Florida slash pine plantations, For. Sci. 32 (1986) 779-788.

[23] Hogg E.H., Temporal scaling of moisture and the forest-grassland boundary in western Canada, Agric. For. Meteorol. 84 (1997) $115-122$.
[24] Holmes R.L., Computer-assisted quality control in tree-ring dating and measurement, Tree-Ring Bulletin 43 (1983) 69-78.

[25] Huffman J.M., Judd W.S., Vascular flora of Myakka River State Park, Sarasota and Manatee counties, Florida, Castanea 63 (1998) $25-50$.

[26] Keeley J.E., Population differentiation along a flood frequency gradient- physiological adaptations to flooding in Nyssa sylvatica, Ecol. Monogr. 49 (1979) 89-108.

[27] Langdon O.G., Growth patterns of Pinus elliottii var. densa, Ecology 44 (1963) 825-827.

[28] Little E.L., Dorman K.W., Slash pine (Pinus elliottii), including south Florida slash pine nomenclature and description, USDA Forest Service Southeastern Forest Experiment Station, Station Paper 36, Asheville, 1954.

[29] Megonigal J.P., Day F.P., Effects of flooding on root and shoot production of bald cypress in large experimental enclosures, Ecology 73 (1992) 1182-1193.

[30] Meinzer F.C., Andrade J.L., Goldstein G., Holbrook N.M., Cavelier J., Wright S.J., Partitioning of soil water among canopy trees in seasonally dry tropical forest, Oecologia 121 (1999) 293-301.

[31] Mitchell R.J., Kirkman L.K., Pecot S.D., Wilson C.A., Palik B.J., Boring L.R., Patterns and controls of ecosystem function in longleaf pine-wiregrass savannas. I. Aboveground net primary productivity, Can. J. For. Res. 29 (1999) 743-751.

[32] Monk C.D., Successional and environmental relationships of the forest vegetation of north central Florida, Am. Midl. Nat. 79 (1968) 441-457.

[33] Monserud R.A., Time-series analyses of tree-ring chronologies, For. Sci. 32 (1986) 349-372.

[34] Myers N., Mittermeier R.A., Mittermeier C.G., daFonseca G., Kent J., Biodiversity hotspots for conservation priorities, Nature 403 (2000) 853-858.

[35] NOAA, U.S. National/State/Divisional Data, Florida Region 4 precipitation, 1999.

[36] NOAA, GHCN Max/Min Temperature, Arcadia FL 27.23N 81.85W, 1999.

[37] Parker A.J., Parker K.C., Faust T.D., Fuller M.M., The effects of climatic variability on radial growth of two varieties of sand pine (Pinus clausa) in Florida, USA, Ann. For. Sci. 58 (2001) 333-350.

[38] Phipps R.L., Simulation of wetlands forest vegetation dynamics, Ecol. Model. 7 (1979) 257-288.

[39] Ross M., An action plan to conserve the native plants of Florida, Southeast Environmental Research Program (SERP), Florida International University and Center for Plant Conservation, Miami/ St. Louis, 1995.

[40] Schweingruber F.H., Eckstein D., Serre-Bachet F., Braker O.U., Identification, presentation, and interpretation of event years and pointer years in dendrochronology, Dendrochronologia 8 (1990) 9-38.

[41] Shan J.P., Morris L.A., Hendrick R.L., The effects of management on soil and plant carbon sequestration in slash pine plantations, $\mathrm{J}$. Appl. Ecol. 38 (2001) 932-941.

[42] Stokes M.A., Smiley T.L., An Introduction to Tree-ring Dating, The University of Arizona Press, Tucson, 1968.

[43] Sun G., Riekerk H., Korhnak L.V., Ground-water table rise after forest harvesting on cypress-pine flatwoods in Florida, Wetlands 20 (2000) 101-112.

[44] Sun H., Furbish D.J., Annual precipitation and river discharges in Florida in response to El Niño- and La Niña-sea surface temperature anomalies, J. Hydrol. 199 (1997) 74-87.

[45] USGS, Historical streamflow daily values for Myakka River near Sarasota Fl (02298830), 1999.

[46] West D.C., Doyle T.W., Tharp M.L., Beauchamp J.J., Platt W.J., Downing D.J., Recent growth increases in old-growth longleaf pine, Can. J. For. Res. 23 (1993) 846-853.

[47] White E.H., Pritchett W.L., Water table control and fertilization for pine production in the flatwoods, Tech. Bull. Fla. Agric. Exp. Stn. (1970) No. 743

[48] Yamaguchi D.K., A simple method for cross-dating increment cores from living trees, Can. J. For. Res. 21 (1991) 414-416. 